\title{
Awareness of HIVIAIDS Among Pregnant Women
}

\author{
SILVIA C. DORON \\ scdoron50@universityofbohol.edu.ph \\ http://orcid.org/0000-0003-2394-4429 \\ MARIA LOURDES B. LANADA \\ mlblañada@universityofbohol.edu.ph \\ https://orcid.org/0000-0002-5892-2791 \\ JEANETTE B. LADAGA \\ jeanetteladaga@gmail.com \\ https://orcid.org/0000-0003-2038-4841 \\ EDUVEGIS L. MALABOTE \\ eduvegismalabote@gmail.com \\ https://orcid.org/0000-0003-1486-2448 \\ HIDELIZA C. REJAS \\ hidelizarejas@gmail.com \\ https://orcid.org/0000-0003-3325-654X
}

\begin{abstract}
The Human Immunodeficiency Virus (HIV) is considered a potentially life-threatening virus that damages the immune system. HIV infection can lead to AIDS (or Acquired Immunodeficiency Syndrome), which is a complex illness with a wide range of complications and symptoms. AIDS is the final stage of HIV. When individuals reach this stage, they are at high risk for opportunistic infections due to their severely damaged immune system, which could lead to death. It affects everyone, including pregnant women.
\end{abstract}


The primary objective of this study is to determine the level of awareness of HIVIAIDS among pregnant women in Manga District, Tagbilaran City. This study used descriptive normative survey method with 19-item awareness questions to 36 expectant mothers. The findings revealed that the respondents were strongly aware of HIVIAIDS. There was a significant relationship between the age and the educational attainment to the level of HIVIAIDS awareness among pregnant mothers in Manga District. An HIVIAIDS Advocacy program should be implemented and cascaded to all women regardless of age, sex, and educational level to help prevent the spread of the disease.

Keywords: HIV, AIDS, virus, disease, infection, pregnancy, expectant mothers, awareness, advocacy, Philippines

\section{INTRODUCTION}

Human Immunodeficiency Virus (HIV) is a retrovirus that passes to the cells of the human immune system, thereby, damaging its normal function (World Health Organization, Health Topics on HIVIAIDS Publication, 2018). As it advances, the body's immune system will become weaker, and the person is more susceptible to many different kinds of infections. It will take 10-15 years for a person living with HIV to develop the most advanced stage of the illness, which is the Acquired Immunodeficiency syndrome AIDS. Taking antiretroviral drugs can lower the spread of HIV infection.

HIV can be contracted through unprotected sexual intercourse (anal or vaginal), blood transfusion, and from a mother and her infant during pregnancy, childbirth, breastfeeding, sharing of contaminated needles. As of June 2016, there were a reported 841 cases of new HIV antibody seropositive individuals according to the HIVIAIDS \& Anti-Retroviral Therapy (ART) Registry of the Philippines (HARP). Such a figure was $9 \%$ or 69 cases higher as compared to the same period in 2015. Such a number was the highest among cases ever reported since 1984. Asymptomatic cases for this particular period were at 88 percent of the said individuals.

The Province of Bohol has reported HIVIAIDS cases. However, no literature can be found in studies that have been conducted on this concern about the possibility of pregnant women to acquire the HIV virus. Further, in some settings, re-testing late in pregnancy or at labor and delivery may be warranted to detect acute HIV infection and immediately 
begin antiretroviral therapy to decrease maternal to child transmission risk. No local studies were addressing this issue.

Hence, the researchers conducted this particular research in the hope to prevent such occurrences. This study would serve as the baseline for an advocacy program. This advocacy program could at least help prevent expectant mothers from acquiring HIVIAIDS.

A combination of several theories which complements other theories applies to this study. The triangular model is fitted for studies on infectious disease. The spread of contagious disease requires a susceptible host and an infective agent, in an environment that brings them together:

Agent, Host Environment Model. This study is anchored on this theory in the sense that HIV refers to the agent if transmitted, pregnant mothers refer to the host and their knowledge of HIVIAIDS refers to how they interact with their environment (Leavell and Clark,1965).

Determining the level of HIVIAIDS awareness could at least help pregnant women from contracting HIVIAIDS. Proper information on HIV/ AIDS is crucial to the effectiveness of the response. Educating pregnant women on this kind of disease will lessen stigma and discrimination that impedes efforts to halt its spread. A robust communication process helps empower people to pursue behavior change.

Social cognitive theory (SCT). Social cognitive theory (SCT) posits that learning occurs in a social context with a dynamic and reciprocal interaction of the person, environment, and behavior. The theory is the anchor that human behavior is being determined by knowledge, communication, or interacting with other people and their practices. Pregnant mothers can be prevented from acquiring the virus when they are educated about the nature of the disease, transmission, and prevention of HIVIAIDS and their behavior could be at least modified once they are knowledgeable about the condition (Bandura, 2002).

The United Nations Agenda for 2030 Sustainable Development Goals focus on the $5 \mathrm{Ps}$, namely People: the wellbeing of all people, Planet: protection of the earth's ecosystems, Prosperity: continued economic and technological growth, Peace: securing peace, Partnership: improving international cooperation.

The No. 3 agenda is to ensure healthy lives and promote wellbeing for all at all ages. It further states that by 2030 there will be an end of occurrences of epidemics, including AIDS. 
Knowing the level of awareness of HIVIAIDS among women, especially pregnant women, is very important to achieving sustainable development goals.

A study entitled "HIV knowledge among pregnant Latinas in rural South Carolina" by Torres, Murray, Meetze, Gaul, and Sutton (2017) revealed that these expectant women had high HIV knowledge which is in agreement with the result of this study. Though, other studies suggest suboptimal HIV knowledge scores among pregnant (mostly African-American) women in the US. In the same study, some pregnant Latinas with low educational attainment, high poverty level, and limited English-Spanish language proficiency in health care settings where social and structural factors contributed to subsequent increasing perinatal HIV risk. Some other studies found sub-optimal HIV knowledge, and screening practices by prenatal providers in the US contributed to low HIV knowledge among pregnant women.

A study conducted on "HIVIAIDS Awareness and Knowledge among Ghanaian Women of Reproductive Age" (Nketiah-Amponsah, Codjoe, Ampaw, 2018) revealed that older Ghanaian women were significantly different from their younger counterparts in terms of socio-economic, and demographic characteristics. Such finding influenced their awareness of HIV/ AIDS. The respondents' age, place of residence, wealth status, education, marital status, and religious affiliation were significantly associated with awareness of HIVIAIDS among women.

The results of a study about the knowledge among the physiotherapist on the mode of transmission by Gurung \& Kamalanathan (2017) showed that majority of the participants agreed that HIV was transmitted by sharing needles with HIV infected person (98.3\%), transfusion of HIV-infected blood or receiving HIV-infected organ (97.9\%), from an HIV-positive mother to her fetus (89.7\%), through breastfeeding from an HIV-infected mother (64.3\%), by sharing personal items such as shaving blades (79.4\%) and having tattoos or body piercings (77\%). Most of the participants disagreed on the transmission of HIV by sharing a meal with an HIV-infected person (84.5\%), using a public swimming pool or public toilet (81.4\%) and casual contacts such as hugging or touching an HIV- infected person (93.8\%).

A study on "Awareness and Knowledge of Mother-to-Child Transmission of HIV among Pregnant Women" intended to assess the awareness and knowledge of mother-to-child transmission of HIV and its corresponding prevention among expectant mothers attending the antenatal clinic of a 
Federal Medical Center in Nigeria. Questionnaires were administered to the respondents at antenatal booking, before being counseled on HIV/ AIDS. Findings showed that all respondents were aware of HIVIAIDS. Their primary sources of information included posters/billboards $(37 \%)$, radio $(36 \%)$, television $(28 \%)$ and health workers $(34 \%)$. The majority $(90 \%)$ of them were aware that HIVIAIDS could be acquired with pregnancy, but only $68 \%$ were aware of mother-to-child transmission. The transplacental route, vaginal delivery, and breastfeeding were identified as routes of transmission from mother to child by 65 percent, 38 percent, and 52 percent of respondents, respectively. Cesarean section was believed to be a route of transmission by $43 \%$ of respondents, but the $3 \%$ identified cesarean section as a method of prevention of mother-to-child transmission (Abiodun, Munir'deen, \& Aboyeji, 2007).

A study entitled "HIVIAIDS Knowledge and Risk Behavior in Hong Kong Chinese Pregnant Women" determined the knowledge of HIV/ AIDS, risk behavior, management, and attitudes towards HIV screening. Findings revealed that expectant mothers in Hong Kong had a reasonably good understanding of HIVIAIDS, but were less knowledgeable on specific mother-to-child HIV transmission (Ho \& Loke, 2003).

A study on Awareness of HIVIAIDS and the household environment of pregnant women in Pune, India. The International Journal of STD \& AIDS showed that $75 \%$ of women were knowledgeable on transmission routes, $70 \%$ were knowledgeable of maternal to child transmission, and $8 \%$ were aware of other preventive measures. Access to information mostly came from television and written materials, rather than radio and other individuals. Thirty percent were physically and mentally abused women, or alcohol and drug abusers. Women who were abused had high knowledge of HIVIAIDS in comparison to women who were not harmed. There was no significant relationship between abuse and educational level of a woman, husband, occupation of either partner, language or religion and no relationship between the knowledge of HIV and risk of abuse in the household (Shrotri, Shankar, Sutar, Joshi, Suryawanshi, Pisal, \& Sastry, 2003).

Another study conducted on "Knowledge and Attitude toward HIV Voluntary Counseling and Testing Services among Pregnant Women Attending an Antenatal Clinic in Sudan" revealed that out of 1,005 women interviewed, $79 \%$ were knowledgeable on HIVIAIDS. Those who belonged to ages 26 years and above and had secondary level education 
were found to be more knowledgeable. The majority were aware of mother to child transmission and willing to undergo testing. But there was still a need to expand voluntary counseling and testing in all prenatal clinics. (Mahmoud, Nasr, Gassmelseed, Abdalelhafiz, Elsheikh, \& Adam, 2007)

A research study entitled "Knowledge and perceptions of HIVIAIDS and mother to child transmission among antenatal mothers at Nnamdi Azikiwe University Teaching Hospital, Nnewi" was aimed to examine the knowledge and perceptions on HIVIAIDS and mother to child transmission among pregnant women. Majority of the 312 respondents $(94.2 \%)$ were aware that HIV infection could coexist with pregnancy, and $76.9 \%$ were aware of mother to child transmission (Igwegbe and llika, 2005).

\section{RESEARCH METHODOLOGY}

The study employed a quantitative approach with the aid of questionnaires to answer the stated problems. The 36 respondents that comprised $31 \%$ of the 114 pregnant women in Manga District, Tagbilaran City, Philippines were randomly selected from July to December 2017. A modified questionnaire was used based on the Assessment tool for HIVIAIDS Awareness by the Health Action Information Network (HAIN) and DOH-Center for Disease Control and Prevention. It was composed of two parts. Part 1 was the socio-demographic profile, and the second part was the questions on the level of awareness. The respondents were chosen regardless of age and social status in the community.

The researchers obtained approval from the University of Bohol Research Ethics Committee (UB-REC) to proceed with the study. The researchers invited, explained the purpose of the study, and sought the permission of the pregnant women in the study site to participate in the survey. An assurance was given to the participants that complete anonymity and utmost confidentiality would be observed in the handling, processing, managing and archiving of the data.

The data were managed, analyzed and interpreted using the following, frequencies, percentages, weighted mean, and Chi-Square. 


\section{RESULTS AND DISCUSSION}

The majority of the respondents were between ages 26-35 years old. Almost two-thirds $(61.1 \%)$ of the respondents were married. Eighty-eight percent of the respondents were Roman Catholics, and most of the respondents $(41.6 \%)$ were high school graduates, while college graduates were at $25 \%$ Housekeepers made up the highest number of respondents, followed by government employees. Third were vendors, and the fourth were office workers and Barangay Health Workers $(\mathrm{BHW})$. Most of the employees had only one child.

Table 1. Level of awareness on Human Immunodeficiency Virus (HIVIAIDS) among pregnant women

N-36

\begin{tabular}{|c|c|c|c|c|c|c|c|}
\hline Nature of HIV IAIDS & $\begin{array}{l}\text { Highly } \\
\text { Aware } \\
\text { ( HA ) }\end{array}$ & $\begin{array}{l}\text { Moderately } \\
\text { Aware } \\
\text { ( MA) }\end{array}$ & $\begin{array}{l}\text { Slightly } \\
\text { Aware } \\
\text { ( SLA ) }\end{array}$ & $\begin{array}{l}\text { Unaware } \\
\text { (U) }\end{array}$ & $\begin{array}{c}\text { Weighted } \\
\text { Mean }\end{array}$ & $\begin{array}{l}\text { Interpre- } \\
\text { Tation }\end{array}$ & RANK \\
\hline $\begin{array}{l}\text { 1. HIV stands for Human } \\
\text { Immunodeficiency Virus. }\end{array}$ & 27 & 5 & 2 & 2 & 3.58 & $\mathrm{HA}$ & 2 \\
\hline $\begin{array}{l}\text { 2. HIV weakens your } \\
\text { immune system by } \\
\text { destroying cells that fight } \\
\text { disease and infection. }\end{array}$ & 24 & 8 & 4 & 0 & 3.56 & $\mathrm{HA}$ & 3 \\
\hline $\begin{array}{l}\text { 3. HIV infection can lead } \\
\text { to AIDS. }\end{array}$ & 24 & 6 & 4 & 2 & 3.44 & $\mathrm{HA}$ & 4 \\
\hline $\begin{array}{l}\text { 4. AIDS is the final stage } \\
\text { of HIV. }\end{array}$ & 21 & 11 & 2 & 2 & 3.42 & $\mathrm{HA}$ & 5 \\
\hline $\begin{array}{l}\text { 5. AIDS is a complex } \\
\text { illness with a wide range } \\
\text { of complications and } \\
\text { symptoms. }\end{array}$ & 27 & 7 & 2 & 0 & 3.69 & $\mathrm{HA}$ & 1 \\
\hline $\begin{array}{l}\text { 6. HIV is found in blood, } \\
\text { semen, breast milk and } \\
\text { vaginal fluids. }\end{array}$ & 16 & 16 & 2 & 2 & 3.28 & $\mathrm{HA}$ & 6 \\
\hline COMPOSITE MEAN & & & & & 3.50 & $\mathrm{HA}$ & \\
\hline $\begin{array}{l}\text { HIV can be transmitted } \\
\text { through: }\end{array}$ & & & & & & & \\
\hline $\begin{array}{l}\text { 7. Sexual intercourse } \\
\text { with an infected person. }\end{array}$ & 27 & 6 & 2 & 1 & 3.64 & $\mathrm{HA}$ & 1 \\
\hline $\begin{array}{l}\text { 8. Using/ Sharing } \\
\text { contaminated needles } \\
\text { and syringes. }\end{array}$ & 17 & 14 & 2 & 3 & 3.25 & $\mathrm{HA}$ & 3 \\
\hline
\end{tabular}




\begin{tabular}{|c|c|c|c|c|c|c|c|}
\hline Nature of HIV IAIDS & $\begin{array}{l}\text { Highly } \\
\text { Aware } \\
\text { ( HA) }\end{array}$ & $\begin{array}{l}\text { Moderately } \\
\text { Aware } \\
\text { (MA) }\end{array}$ & $\begin{array}{l}\text { Slightly } \\
\text { Aware } \\
\text { ( SLA) }\end{array}$ & $\begin{array}{l}\text { Unaware } \\
\text { (U) }\end{array}$ & $\begin{array}{c}\text { Weighted } \\
\text { Mean }\end{array}$ & $\begin{array}{l}\text { Interpre- } \\
\text { Tation }\end{array}$ & RANK \\
\hline $\begin{array}{l}\text { 9. Blood transfusion } \\
\text { with infected blood or an } \\
\text { organ transplant from an } \\
\text { infected donor. }\end{array}$ & 16 & 15 & 2 & 3 & 3.22 & MA & 4 \\
\hline $\begin{array}{l}\text { 10. During pregnancy, } \\
\text { childbirth, or } \\
\text { breastfeeding. }\end{array}$ & 13 & 19 & 0 & 4 & 3.14 & MA & 5 \\
\hline $\begin{array}{l}\text { 11. Injection of illegal } \\
\text { drugs. }\end{array}$ & 18 & 14 & 2 & 2 & 3.33 & $\mathrm{HA}$ & 2 \\
\hline $\begin{array}{l}\text { 12. Occupational } \\
\text { exposure through needle } \\
\text { sticks or cuts. }\end{array}$ & 15 & 14 & 3 & 4 & 3.11 & MA & 6 \\
\hline $\begin{array}{l}\text { 13. Infected individuals } \\
\text { can have the virus for up } \\
\text { to } 10 \text { years-sometimes } \\
\text { longer-without showing } \\
\text { signs or symptoms. }\end{array}$ & 8 & 19 & 5 & 4 & 2.86 & MA & 7 \\
\hline COMPOSITE MEAN & & & & & 3.22 & $\mathrm{HA}$ & \\
\hline $\begin{array}{l}\text { HIV/ AIDS Prevention } \\
\text { 14. Practicing abstinence } \\
\text { and using of a condom. }\end{array}$ & 23 & 10 & 0 & 3 & 3.19 & MA & 6 \\
\hline $\begin{array}{l}\text { 15. Being faithful to one's } \\
\text { partner. }\end{array}$ & 23 & 8 & 3 & 2 & 3.44 & $\mathrm{HA}$ & 5 \\
\hline $\begin{array}{l}\text { 16. Avoid using illegal } \\
\text { drugs }\end{array}$ & 27 & 6 & 0 & 3 & 3.58 & $\mathrm{HA}$ & 1 \\
\hline $\begin{array}{l}\text { 17. HIV testing and } \\
\text { screening }\end{array}$ & 26 & 7 & 0 & 3 & 3.56 & $\mathrm{HA}$ & 25 \\
\hline $\begin{array}{l}\text { 18.Avoid transfusion of } \\
\text { unscreened blood }\end{array}$ & 28 & 3 & 1 & 4 & 3.53 & $\mathrm{HA}$ & 4 \\
\hline $\begin{array}{l}\text { 19. Educate oneself } \\
\text { about HIV/ AIDS }\end{array}$ & 28 & 4 & 0 & 4 & 3.56 & $\mathrm{HA}$ & 25 \\
\hline COMPOSITE MEAN & & & & & 3.48 & $\mathrm{HA}$ & \\
\hline \multicolumn{5}{|c|}{ OVER ALL COMPOSITE MEAN } & 3.4 & \multicolumn{2}{|c|}{ Highly Aware } \\
\hline
\end{tabular}

Legend:

$\begin{array}{llll}\text { Symbol } & \text { Description } & \text { Meaning } & \text { Weighted Mean } \\ \text { HA } & \text { Highly Aware } & \text { Fully aware of the idea } & 3.25-4.00 \\ \text { MA } & \text { Moderately Aware } & \text { Aware of the idea but needs proof } & 2.50-3.24 \\ \text { SLA } & \text { Slightly Aware } & \text { Slightly aware of the idea } & 1.75-2.49 \\ \text { U } & \text { Unaware } & \text { Not aware of the idea } & 1.0-1.74\end{array}$


Table 1 depicts a high level of awareness of pregnant women on the nature, transmission, and prevention of HIVIAIDS. This result means that pregnant women were knowledgeable of HIVIAIDS.

Data revealed that nine respondents aged 31-45 years old, four respondents aged 41-45 and two respondents aged 21-25 were strongly aware of HIVIAIDS. Only one respondent aged between 26-30 was moderately aware, and two 20-year-old respondents were slightly aware, and only one respondent aged between 21-25 was unaware of HIVIAIDS.

One respondent between ages 26-30 was moderately aware, two respondents who were 20 years old were slightly aware of HIVIAIDS and one respondent between 21-25 years of age was unaware of HIVIAIDS.

When testing the degree of relationship between the profile and the levels of HIV AIDS Awareness, the findings revealed that the age of the respondents and their educational attainment affected their level of awareness in HIVIAIDS while civil status, religion, occupation, number of children were insignificant.

Table 2. Testing the Significant Relationship between the Level of Awareness on HIVIAIDS and Age of pregnant women

\begin{tabular}{|c|c|c|c|c|c|c|c|}
\hline \multicolumn{8}{|c|}{ Age } \\
\hline $\begin{array}{l}\text { Awareness } \\
\text { Level of HIVI } \\
\text { AIDS }\end{array}$ & $\begin{array}{l}20 \text { years } \\
\text { Below }\end{array}$ & $21-25$ & $26-30$ & $31-35$ & $36-40$ & $41-45$ & TOTAL \\
\hline $\begin{array}{l}\text { Strongly } \\
\text { Aware } \\
\text { (SA) }\end{array}$ & $\begin{array}{l}1.67 \\
0 \\
1.667\end{array}$ & $\begin{array}{l}4.17 \\
2 \\
1.127\end{array}$ & $\begin{array}{l}7.50 \\
8 \\
0.033\end{array}$ & $\begin{array}{c}7.50 \\
9 \\
0.300\end{array}$ & $\begin{array}{l}5.83 \\
7 \\
0.233\end{array}$ & $\begin{array}{l}3.33 \\
4 \\
0.133\end{array}$ & 30 \\
\hline $\begin{array}{c}\text { Moderately } \\
\text { Aware } \\
\text { ( MA) }\end{array}$ & $\begin{array}{l}0.06 \\
0 \\
0.056\end{array}$ & $\begin{array}{l}0.14 \\
0 \\
0.139\end{array}$ & $\begin{array}{l}0.25 \\
1 \\
2.250\end{array}$ & $\begin{array}{c}0.25 \\
0 \\
0.250\end{array}$ & $\begin{array}{l}0.19 \\
0 \\
0.194\end{array}$ & $\begin{array}{l}0.11 \\
0 \\
0.111\end{array}$ & 1 \\
\hline $\begin{array}{l}\text { Slightly } \\
\text { Aware } \\
\text { (SLA) }\end{array}$ & $\begin{array}{l}0.22 \\
2 \\
14.222\end{array}$ & $\begin{array}{l}0.56 \\
2 \\
3.756\end{array}$ & $\begin{array}{l}1.00 \\
0 \\
1.000\end{array}$ & $\begin{array}{c}1.00 \\
0 \\
1.000\end{array}$ & $\begin{array}{l}0.78 \\
0 \\
0.778\end{array}$ & $\begin{array}{l}0.44 \\
0 \\
0.444\end{array}$ & 4 \\
\hline $\begin{array}{l}\text { Unaware } \\
\text { (U) }\end{array}$ & $\begin{array}{l}0.06 \\
0 \\
0.056\end{array}$ & $\begin{array}{l}0.14 \\
1 \\
5.339\end{array}$ & $\begin{array}{l}0.25 \\
0 \\
0.250\end{array}$ & $\begin{array}{l}0.25 \\
0 \\
0.250\end{array}$ & $\begin{array}{l}0.19 \\
0 \\
0.194\end{array}$ & $\begin{array}{l}0.11 \\
0 \\
0.111\end{array}$ & 1 \\
\hline TOTAL & 2 & 5 & 9 & 9 & 7 & 4 & 36 \\
\hline & & $\begin{array}{r}\text { Critic } \\
\text { Res }\end{array}$ & $\begin{array}{l}X 2=33.8 \\
\text { Il value of } \\
.05=24 . \\
\text { ult: SIGNI } \\
\text { to: REJEC }\end{array}$ & $\begin{array}{l}3 \\
2 \text { at } 15 \mathrm{df} \\
6 \\
\text { CANT } \\
\text { ED }\end{array}$ & & & \\
\hline
\end{tabular}


Twelve secondary graduates, seven postgraduate degree holders, and one elementary graduate were Highly Aware of HIVIAIDS. One graduate of vocational course was moderately knowledgeable, three secondary graduates were slightly aware of HIVIAIDS, and one postgraduate student was unaware of HIVIAIDS.

Table 3. Testing the Significant Relationship between the Level of Awareness on HIVIAIDS and the Educational attainment of pregnant women

\begin{tabular}{|c|c|c|c|c|c|c|}
\hline \multicolumn{7}{|c|}{ Educational Attainment } \\
\hline $\begin{array}{c}\text { Level of } \\
\text { awareness } \\
\text { on HIVIAIDS }\end{array}$ & $\begin{array}{l}\text { Elementary } \\
\text { Graduate }\end{array}$ & $\begin{array}{l}\text { Secondary } \\
\text { Graduate }\end{array}$ & $\begin{array}{l}\text { Tertiary } \\
\text { Graduate }\end{array}$ & Vocational & $\begin{array}{c}\text { Post } \\
\text { Graduate }\end{array}$ & TOTAL \\
\hline $\begin{array}{l}\text { Strongly } \\
\text { Aware } \\
\text { (SA) }\end{array}$ & $\begin{array}{l}1.67 \\
1 \\
0.267\end{array}$ & $\begin{array}{l}12.50 \\
12 \\
0.020\end{array}$ & $\begin{array}{l}7.50 \\
9 \\
0.300\end{array}$ & $\begin{array}{l}1.67 \\
1 \\
0.267\end{array}$ & $\begin{array}{l}6.67 \\
\quad 7 \\
0.017\end{array}$ & 30 \\
\hline $\begin{array}{c}\text { Moderately } \\
\text { Aware } \\
\text { (MA) }\end{array}$ & $\begin{array}{l}0.06 \\
0 \\
0.056\end{array}$ & $\begin{array}{l}0.42 \\
0 \\
0.417\end{array}$ & $\begin{array}{l}0.25 \\
0 \\
0.250\end{array}$ & $\begin{array}{l}0.06 \\
1 \\
16.056\end{array}$ & $\begin{array}{l}0.22 \\
0 \\
0.222\end{array}$ & 1 \\
\hline $\begin{array}{l}\text { Slightly } \\
\text { Aware } \\
\text { (SLA) }\end{array}$ & $\begin{array}{l}0.22 \\
1 \\
2.722\end{array}$ & $\begin{array}{l}1.67 \\
3 \\
1.067\end{array}$ & $\begin{array}{l}1.00 \\
0 \\
1.000\end{array}$ & $\begin{array}{l}0.22 \\
0 \\
0.222\end{array}$ & $\begin{array}{l}0.89 \\
0 \\
0.889\end{array}$ & 4 \\
\hline $\begin{array}{l}\text { Unaware } \\
\text { (U) }\end{array}$ & $\begin{array}{l}0.06 \\
0 \\
0.056\end{array}$ & $\begin{array}{l}0.42 \\
0 \\
0.417\end{array}$ & $\begin{array}{l}0.25 \\
0 \\
0.250\end{array}$ & $\begin{array}{l}0.06 \\
0 \\
0.056\end{array}$ & $\begin{array}{l}0.22 \\
1 \\
2.722\end{array}$ & 1 \\
\hline TOTAL & 2 & 15 & 9 & 2 & 8 & 36 \\
\hline
\end{tabular}

$X 2=27.270$

Critical Value of $x 2$ at $12 \mathrm{df}$

$0.05=21.026$

Result: SIGNIFICANT

Ho: REJECTED

Significant relationships between the respondents' levels of awareness on HIVIAIDS as to age (See Table 2) and educational attainment (See Table 3 ) were observed. However, no significant relationship was found as to the levels of awareness of the respondents on HIVIAIDS as to their occupation, civil status, religion, and number of children 


\section{CONCLUSIONS}

Based on the findings, the following conclusions are drawn:

1. Expectant mothers in Manga District were Highly Aware of HIV and AIDS.

2. There was a significant degree of relationship between the age and educational attainment, to their level of awareness on HIV AIDS.

\section{RECOMMENDATIONS}

Based on the conclusions, the following recommendations are proposed:

1. A need to present the results of the study to the City Health Office, the Local Government Unit, Primary Health Care Unit personnel of Manga and to the Barangay Health Workers (BHW) to inform their programs and policies pertaining the results of this study. In turn, they will be guided on the crafting of their programmatic measures to address the spread of HIV-AIDS.

2. A comprehensive health education program on HIV AIDS must be vigorously implemented in every healthcare facility; especially to those of younger ages and having low educational attainment. Regular promotional activities on HIVIAIDS Awareness should be done.

3. Conduct massive information campaign about HIVIAIDS to the community targeting the younger age group and those with low educational level.

4. Conduct capability building among BHWs as HIVIAIDS educators.

5.Distribution of IEC (information, education, and communication) materials such as brochures and others related educational materials on STI/HIVIAIDS.

\section{REFERENCES CITED}

Abiodun, M. O., Munir'deen, A. I., \& Aboyeji, P. A. (2007). Awareness and knowledge of mother to-child transmission of HIV among pregnant women. Journal of the National Medical Association, 99(7), 758. Retrieved from https://goo.gl/WJSFFU, (accessed last 15 January 2018). 
Bandura, A. (2002). Social cognitive theory in cultural context. Applied psychology, 51(2), 269-290. Retrieved from https://bit.ly/2m58Tgg, (accessed last 15 January 2018).

Gurung, B., \& Kamalanathan, P. (2017). HIVIAIDS Related Knowledge, Attitudes and Risk Perception among the Physiotherapist in Chennai and Suburban Retrieved from https://goo.gl/ppiYEG, (accessed last 26 April 2018).

HIVIAIDS and ART Registry of the Philippines: June 2016. Epidemiology Bureau, Department of Health. (2016). Retrieved from https://goo.gl/ eVb3dy, (accessed last 15 May 2018).

Ho, C. F., \& Loke, A. Y. (2003). HIVIAIDS knowledge and risk behaviour in Hong Kong Chinese pregnant women. Journal of advanced nursing, 43(3), 238-245. Retrieved from https://goo.gl/2BroUe, (accessed last 20 February 2018).

Igwegbe, A. O., \& llika, A. L. (2005). Knowledge and perceptions of HIV/ AIDS and mother to child transmission among antenatal mothers at Nnamdi Azikiwe University Teaching hospital, Nnewi. Nigerian journal of clinical practice, 8(2), 97-101. Retrieved from https://goo.gl/TUkQ3F, (accessed last 20 March 2018).

Mahmoud, M. M., Nasr, A. M., Gassmelseed, D. E. A., Abdalelhafiz, M., Elsheikh, M. A., \& Adam, I. (2007). Knowledge and attitude toward HIV voluntary counseling and testing services among pregnant women attending an antenatal clinic in Sudan. Journal of medical virology, 79(5), 469-473. Retrieved from https://goo.gl/r9wNGd, (accessed last 15 March 2018).

Nketiah-Amponsah, E., Codjoe, E. A., \& Ampaw, S. (2018). HIVIAIDS Awareness and Knowledge Among Ghanaian Women of Reproductive Age: What Are the Correlates? Journal of Asian and African Studies, 54(2), 267-281. Retrieved from https://bit.ly/2kkFnD3, (accessed last 22 June 2018). 
Republic Act 8504. The Philippine AIDS Prevention and Control Act of 1998.

Shrotri, A., Shankar, A. V., Sutar, S., Joshi, A., Suryawanshi, N., Pisal, H., ... \& Sastry, J. (2003). Awareness of HIVIAIDS and household environment of pregnant women in Pune, India. International journal of STD \& AIDS, 14(12), 835-839. Retrieved from https://goo.gl/zTy4ui, (accessed last 20 February 2018).

Thomas, B., Nyamathi, A., \& Swaminathan, S. (2009). Impact of HIVIAIDS on mothers in southern India: a qualitative study. AIDS and Behavior, 13(5), 989. Retrieved from https://goo.gl/E5k5yc, (accessed last 20 January 2018).

Torres, M. E., Murray, A., Meetze, E. G., Gaul, Z., \& Sutton, M. Y. (2017). HIV Knowledge Among Pregnant Latinas in Rural South Carolina. Journal of immigrant and minority health, 19(4), 897-904. Retrieved from https:// bit.ly/2k806d6, (accessed last 22 June 2018).

UNDP. Sustainable Development Goals. Retrieved from https://bit. ly/10Td4Sr, (accessed last 22 June 2018).

World Health Organization. HIVIAIDS definition. Retrieved from https://bit. ly/2m5QOir (accessed last 22 June 2018). 